J. Clin. Chem. Clin. Biochem.

Vol. 16, 1978, pp. 135-144

\title{
The Effect of Encapsulation in Red Blood Cells on the Distribution of Methotrexate in Mice
}

\author{
By U. Zimmermann, G. Pilwat and Brigitte Esser \\ Institute of Biophysical Chemistry, Nuclear Research Center Jülich, Germany
}

(Received August 29/November 1, 1977)

Summary: Red blood cell ghosts containing entrapped methotrexate were injected into mice. The distribution pattern of the drug amongst different organs was markedly different from that observed after the injection of free methotrexate. Methotrexate is trapped inside mice and human red blood cell ghosts by application of an electric field pulse of 8 and $12 \mathrm{kV} / \mathrm{cm}$, respectively, for $40 \mu \mathrm{s}$ through an isotonic red blood cell suspension containing $5 \mathrm{mmol} / \mathrm{l}$ methotrexate between $0-4^{\circ} \mathrm{C}$. The electrical field induces a permeability change of the cell membrane, which results from the dielectric breakdown of the cell membrane, leading to an exchange of ions and macromolecules between the cell interior and the external medium containing the drug. After resealing by raising the temperature to $37^{\circ} \mathrm{C}$, the cells contained about $5 \mathrm{mmol} / \mathrm{l}$ methotrexate. The methotrexate-loaded ghost population, obtained from mouse or human red blood cells, was electrically homogeneous as shown by dielectric breakdown measurements using a hydrodynamic focusing Coulter Counter. $25 \mu \mathrm{g}$ methotrexate labelled with $22 \mathrm{kBq}\left[3^{\prime}, 5^{\prime}, 9(\mathrm{n}) \cdot{ }^{3} \mathrm{H}\right]$ methotrexate (specific activity $0.63 \mathrm{TBq} /$ $\mathrm{mmol}$ ) trapped inside human or mouse ghost cells was injected into the tail vein of mice (about $20 \mathrm{~g}$ body weight). Nearly all of the entrapped methotrexate accumulated in the liver, whereas in control experiments only 0.25 of the injected dose accumulated in the liver. This carrier system can be made specific for other organs by entrapping, in addition to the drug, small para-, ferro-, or ferrimagnetic particles of 4 to $20 \mathrm{~nm}$ in diameter, and by using an external magnetic guide.

\section{Verteilungsspektrum von in Erythrocyten eingeschlossenem Methotrexat in der Maus}

Zusammenfassung: Das Verteilungsspektrum von intravenös injiziertem Methotrexat im Organismus einer Maus läßt sich signifikant verändern, wenn Erythrocyten als Pharmakon-Trägersysteme verwendet werden. Der Einschluß von Methotrexat in Erythrocyten erfolgt mit Hilfe einer Feldpulstechnik. Applikation eines elektrischen Feldpulses von 8 bzw. $12 \mathrm{kV} / \mathrm{cm}$ Feldstärke und $40 \mu$ s Dauer in eine gekühlte $\left(0-4^{\circ} \mathrm{C}\right)$ isotone Erythrocytensuspension, die $5 \mathrm{mmol} / 1$ Methotrexat enthält, induziert einen dielektrischen Durchbruch der Zellmembranen der Erythrocyten, der zu einer starken Permeabilițätsänderung der Zellmembran und demzufolge zu einem Austausch der zellulären Bestandteile mit denen der Außenlösung führt. Die ursprünglichen Permeabilitätseigenschaften der Zellmembran werden durch Erhöhung der Temperatur auf $37^{\circ} \mathrm{C}$ regeneriert. Die mit $5 \mathrm{mmol} / 1$ Methotrexat beladenen Erythrocytenpopulationen von Mäusen und Menschen waren elektrisch homogen, wie Untersuchungen mit einem hydrodynamisch fokussierenden Coulter Counter zeigten. $25 \mu \mathrm{g}$ Methotrexat, die mit $22 \mathrm{kBq}\left[3^{\prime}, 5^{\prime}, 9(\mathrm{n}){ }^{3} \mathrm{H}\right]$ Methotrexat markiert waren, wurden in die Schwanzvene von Mäusen (etwa $20 \mathrm{~g}$ Körpergewicht) injiziert. Fast das-gesamte Methotrexat, das sowohl in Menschen- wie auch Mäuseerythrocyten eingeschlossen wurde, konnte zur Leber dirigiert werden, während in Kontrollversuchen nur etwa 0,25 des frei injizierten Methotrexates in diesem Organ akkumuliert wurde. Spezifität dieser Trägersysteme für andere Organe und Gewebe kann über den simultanen Einschluß von para-, ferro- oder ferrimagnetischen Substanzen von 4 bis $20 \mathrm{~nm}$ Durchmesser und über externe magnetische Lenkung dieser „magnetischen Erythrocyten" erzielt werden.

\section{Introduction}

The conventional forms of drug dosage in human therapeutics are limited in their lack of organ-specificity and short duration time of delivery. High concentrations of drugs together with high frequencies of drug administration are often required. This results in detrimental side effects and in the inability to use pharmacological agents with short biological half-lives. These inherent problems have motivated the research and development of drug delivery systems that meet the 
following criteria: continuous control of spatial and temporal delivery patterns, and extended operational delivery times. The superiority of controlled drug release systems over conventional dosage systems lies in the safety, i. e. less severe side effects, and in the therapeutic effectiveness. The controlled spatial and temporal administration of a specific drug achieved by drug delivery systems is expected to bring about a pronounced alteration in the pharmaceutical spectrum.

The majority of the research and development in the field of therapeutic drug delivery systems is geared towards the encapsulation of drugs and enzymes in synthetic membrane capsules $(1,2)$. The membrane protects the external environment from the drug and modulates the spatial and temporal release of the drug into the body's fluid and tissue by the permeability of the membrane envelope. The principal difficulties underlying the use of such drug containing synthetic membrane capsules remain largely unsolved. They lie in the need for membrane systems which have optimal properties for both the encapsulation of a broad diversity of drugs, and the controlled release of the drug in time and space.

Recently we (3-6) suggested the use of biomembranes instead of synthetic membranes for drug encapsulation; that is to load living cells, such as red blood cells and lymphocytes, with a specific drug. Originally the idea to encapsulate molecules inside cells was suggested by Zimmermann $(7,8,9)$, Zimmermann et al. (10) and independently by Ihler et al. (11) in relation to the treatment of enzyme deficiency diseases. The problem of biocompatibility is easily circumvented if the patient's own blood is used in conjunction with therapeutically tested, commercial drugs. The danger of toxicity, of immunological responses, and other adverse reactions that are conceivably introduced by the synthetic membrane systems are thereby avoided.

In this study, we report the encapsulation of methotrexate (Amethopterin; 4-amino- $\mathbf{N}^{\mathbf{1 0}}$-methylpteroylglutamic acid) in red blood cells. Clinically relevant amounts of methotrexate could be entrapped inside the red blood cells by dielectric breakdown techniques. Dielectric breakdown of the cell membrane occurs in isotonic solutions in response to an externally applied electric field pulse of high strength and short duration (12). The subsequent haemolysis in isotonic solution (under various conditions) leads to a broad spectrum of homogeneous ghost populations of different drug release characteristics (13), a prerequisite for a broad application of this cellular carrier system in therapeutics and diagnosis.

Efforts were made to prepare electrically methotrexateloaded ghost cells which are directed completely to the liver. From the standpoint of liver tumor treatment it is desirable to preferentially accumulate drugs (or radio- active isotopes for local radiation) in the liver. In addition, the target specificity for the liver can be relatively easily obtained by using cells, which differ in size, deformability and surface charge from intact red blood cells, in the spleen and the liver. However, as pointed out below, modified red blood cell systems can be directed to any other site of the body.

Methotrexate was used because of the success of this agent in chemotherapeutic cancer treatment. Methotrexate is the most widely studied and clinically useful folate antagonist (14-18). It is a powerful inhibitor of the enzyme dihydrofolate reductase and has similar binding affinities for this enzyme both from normal mammalian tissues and from neoplastic tissues (19).

Thus the selectivity of this agent against tumors depends upon the use of a specific transport system for the administration of the drug. The amount of methotrexate accumulated within the cells of the tissue is dependent on the concentration in the blood, as there is a substantial body of evidence to suggest that the drug concentration in the tissue attains a rapid equilibrium with that in the blood $(19,20)$. The drug concentration in the blood is controlled by its removal in the kidney and intestine. $6 \mathrm{~h}$ after intravenous injection, methotrexate is almost completely excreted from men (21), whereas in mice the drug is eliminated after almost $1 \mathrm{~h}(20)$. Therefore, intermittent parenteral administration of methotrexate, which increases the plasma concentration for a short time and, in turn, the intracellular drug concentration, is more effective than long term low doses. The high frequency and the high levels necessary for treatment, on the other hand, limit the application of methotrexate because of the severe side effects observed in treated patients. For these reasons methotrexate was used in testing the effectiveness of red blood cells in organ-specific administration.

\section{Materials and Methods}

Human blood was collected from apparently healthy donors. The blood was centrifuged $(4000 \mathrm{~g}, 5 \mathrm{~min})$, the buffy coat leucocyte layer was removed, the cells were washed several times and centrifuged with the following solution I: $138.6 \mathrm{mmol} / \mathrm{l} \mathrm{NaCl}$, $12.3 \mathrm{mmol} / 1 \mathrm{Na}_{2} \mathrm{HPO}_{4}, 2.7 \mathrm{mmol} / 1 \mathrm{NaH}_{2} \mathrm{PO}_{4}, \mathrm{pH} 7.4$. Mice blood was obtained from young male and female adult mice (ca. $18-22 \mathrm{~g})$. The blood was subjected to the same procedure.

\section{Haemolysis}

Electrical haemolysis of red blood cells in isotonic solutions is described in detail by Zimmermann \& Pilwat (cf. 22, 12, 13). For the sake of clarity a brief outline of the procedure is presented.

If not otherwise stated the red blood cells were suspended in a solution containing $105 \mathrm{mmol} / 1 \mathrm{KCl}, 20 \mathrm{mmol} / \mathrm{l} \mathrm{NaCl} ; 4 \mathrm{mmol} / 1$ $\mathrm{MgCl}_{2}, 7.6 \mathrm{mmol} / 1 \mathrm{Na}_{2} \mathrm{HPO}_{4}, 2.4 \mathrm{mmol} / 1 \mathrm{NaH}_{2} \mathrm{PO}_{4}$ and 10 . $\mathrm{mmol} / \mathrm{l}$ glucose (solution II). The $\mathrm{pH}$ of the solution was adjusted to 7.2. The suspension density was 1:10 (packed cells to solution). An exponentially decaying electric field is applied to 
$10 \mathrm{ml}$ of the red blood cell suspension by discharging a capacitor using a spark gap (22). The electric field strength was 8 and 12 $\mathrm{kV} / \mathrm{cm}$, respectively (peak value) and the pulse duration characterized by the decay constant was about $40 \mu \mathrm{s}$. The temperature of the suspension was kept at $0-4^{\circ} \mathrm{C}$. Haemolysis and equilibration with the external solution occurs in about $5 \mathrm{~min}$. Methotrexate and $\left[3^{\prime}, 5^{\prime}, 9(\mathrm{n})^{3} \mathrm{H}\right]$ methotrexate (1.9 GBq, Amersham, specific activity $0.63 \mathrm{TBq} / \mathrm{mmol}$ ) can be added either before or 1 to $2 \mathrm{~min}$ after electric field application. The lysed cells were loaded with $5 \mathrm{mmol} / \mathrm{l}$ methotrexate which corresponds to clinically relevant drug concentrations. Resealing of the cells was conducted at different temperatures. In the experiments reported here the ghost cells were kept for $10 \mathrm{~min}$ between $0-4^{\circ} \mathrm{C}$, after which the temperature was raised to $37^{\circ} \mathrm{C}$ for $30 \mathrm{~min}$ (both for human and mice ghost cells). The ghost cells were then centrifuged at $10,000 \mathrm{~g}$ for $10 \mathrm{~min}$ and reincubated after several washings in solution $I$. The concentration of methotrexate entrapped in the cells was on average $\mathbf{0 . 8 0}$ of that in the outer solution.

\section{Coulter Counter measurements}

The mean volume of the loaded ghost population was measured with a hydrodynamically focusing Coulter Counter (AEG-Telefunken, Ulm, West-Germany). The size distributions wore measured at increasing electric field strengths in the orifice of the Coulter Counter (orifice dimensions: $60 \mu \mathrm{m}$ in length and diameter). From the apparent shift of the size distribution, which results from the dielectric breakdown of the cell membrane, once a ccrtain threshold value of the external electric ficld in the orifice has been reached $(23,24,25)$, conclusions can be drawn with regard to the homogeneity and the electrical properties of the cell membranes of the ghost population (10).

Degradation of ghost cells in mice and determination of blood volume

Mouse red blood cells were labelled with $99 \mathrm{~m}$ Tc by the procedure described by Hedge et al (26). $0.5 \mathrm{ml}$ mouse red blood cells and ghost cells, respectively, were incubated for $5 \mathrm{~min}$ at room temperature with $3.7 \mathrm{MBq} 99 \mathrm{~m} \mathrm{Tc}$ dissolved in $9 \mathrm{~g} / \mathrm{l}$ $\mathrm{NaCl} .5 \mu \mathrm{l}$ of a solution containing $10 \mathrm{~g} / 1 \mathrm{SnCl}_{2}$ was added and the mixture allowed to stand for a further $5 \mathrm{~min}$. The cells were then centrifuged and washed twice with solution I, being resuspended in solution $I$ at a suspension density of $1: 10.100 \mu l$ of this suspension was then injected into the tail vein of the mice. Samples were taken 10 and 30 min after injection and the radioactivity was determined in aliquots. The total blood volume was estimated by comparing the radioactivity of the sample with the total amount of Tc injected into the tail.

Preparation of samples for scintillation counting The mice were killed at certain time intervals over a $3 \mathrm{~h}$ period after injection of loaded cells into the tail vein. Organ samples were taken from lung, heart, liver, spleen, kidney, stomach, intestine, duodenum, blood, serum, urine, and feces. All tissue samples were freeze dried, ground, and aliquots solubilized in Soluene 100 (Packard). Instagel (Packard) was added after bleaching the samples with hydrogen peroxide.

The samples were counted in a Tricarb liquid scintillation spectrometer (Packard). The count rates were corrected for quenching using the external standard ratio method.

\section{Results}

\section{Haemolysis of mouse red blood cells}

There are two principle procedures used to encapsulate drugs in red blood cells. Red blood cells can be loaded by subjecting them to osmotic stress in media of low tonicity and ionic strength at about $0^{\circ} \mathrm{C}$. Under these conditions the cells haemolyse and the cell interior equilibrates with the external medium. By this procedure a drug which is added to the external medium is diffused into the cell interior. Restoration of the tonicity of the external medium and increasing the temperature to $37^{\circ} \mathrm{C}$ leads to a resealing of the membrane with the drug trapped inside the cell. Osmotic haemolysis was used for the entrapment of enzymes and other macromolecules by Zimmermann (7), by Ihler (11), by Updike et al. (27), and by Adriaenssens et al. (28).

This procedure is limited for a broader routine clinical application due to several reasons. For example, loading of cells by osmotic lysis is a very time consuming process and the transient low ionic strengths of the solution to which the cells are exposed during haemolysis may alter the membrane composition and integrity $(29,30)$. This, in turn, leads to a decrease in the half-life of the loaded cells due to cell degradation in the spleen and the liver, and also limits both a long-term application or a specific short-term application at other tissue and organ sites (see below).

The limitations of osmotic haemolysis were overcome by electrical haemolysis of red blood cells in isotonic solutions $(10,13)$. Electrical haemolysis is induced by the dielectric breakdown of the cell membrane once a critical membrane potential is exceeded in response to an external applied electric field pulse of $\mu$ s duration. The apparent critical membrane potential of the red blood cell membrane is of the order of 0.6 to $1.0 \mathrm{~V}$ (depending on the pulse length of the applied electric field pulse (12)). These values correspond to an external, exponentially decaying field pulse of $2 \mathrm{kV} / \mathrm{cm}$ and $40 \mu$ s duration $(12,13)$. The breakdown of the cell membrane leads to a permeability change of the cell membrane which induces a redistribution of sodium and potassium. At supercritical field strengths several breakdown areas are generated in the membrane, thus the permeability of the membrane is so significantly altered that the redistribution of sodium and potassium is complete. As a result of this the cells swell osmotically and subsequently haemolysis occurs. Since the generation of the critical breakdown voltage across the cell membrane is dependent on the cell size, higher electric field strengths are required to haemolyse the whole cell population.

A typical set of haemolysis curves in dependence on the external applied electric field strength is presented in figure 1 for mouse red blood cells suspended in $9 \mathrm{~g} / 1$ $\mathrm{NaCl}$ solution (containing $4 \mathrm{mmol} / \mathrm{l} \mathrm{Tris} / \mathrm{HCl}$ ) and in solution II. The degree of haemolysis was measured in the supernatant $10 \mathrm{~min}$ after field application keeping the temperature of the cell suspension throughout this whole process, between 0 and $4^{\circ} \mathrm{C}$. Haemolysis can be prevented in this field range by adding increasing concentrations of sucrose or larger non-electrolytes to the external solution or by the presence of increasing con- 


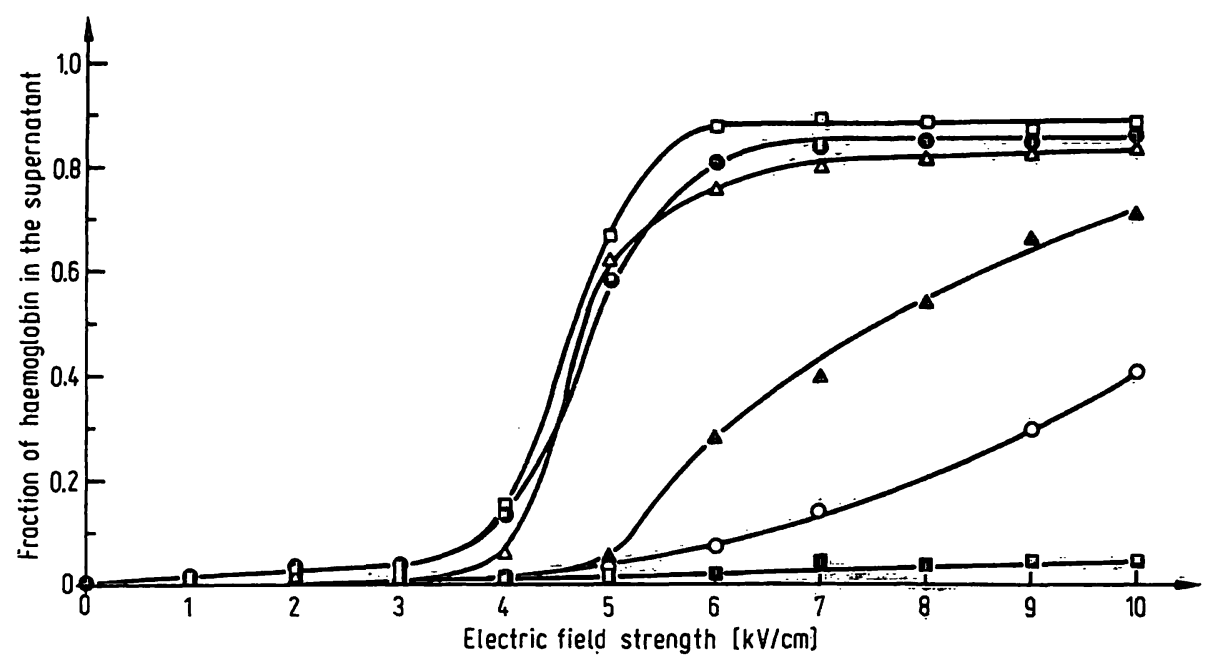

Fig. 1. The effect of different composition of the external solution on the electric field strength (peak values) required for haemolysis of mouse erythrocytes. The pulse length of the applied external field was $40 \mu \mathrm{s}$. For further experimental details, see Methods and Results.

- $154 \mathrm{mmol} / 1 \mathrm{NaCl}$ and $4 \mathrm{mmol} / \mathrm{l} \mathrm{Tris} / \mathrm{HCl}, \mathrm{pH} 7.2$

- - $105 \mathrm{mmol} / 1 \mathrm{KCl}, 20 \mathrm{mmol} / 1 \mathrm{NaCl}, 4 \mathrm{mmol} / 1 \mathrm{MgCl}_{2}, 7.6 \mathrm{mmol} / 1 \mathrm{Na}_{2} \mathrm{HPO}_{4}, 2.4 \mathrm{mmol} / \mathrm{l} \mathrm{NaH} \mathrm{PO}_{4}$, and $10 \mathrm{mmol} / 1$ glucose, $\mathrm{pH} 7.2$ (solution II) (total phosphate concentration: $10 \mathrm{mmol} / \mathrm{l}$ )

$\triangle \longrightarrow \Delta 154 \mathrm{mmol} / 1 \mathrm{NaCl}, 4 \mathrm{mmol} / 1 \mathrm{Tris} / \mathrm{HCl}$, and $10 \mathrm{mmol} / 1$ sucrose

A- $123.2 \mathrm{mmol} / 1 \mathrm{NaCl}, 24.6 \mathrm{mmol} / 1 \mathrm{Na}_{2} \mathrm{HPO}_{4}$, and $5.4 \mathrm{mmol} / 1 \mathrm{NaH}_{2} \mathrm{PO}_{4}$ (total phosphate concentration $30 \mathrm{mmol} / \mathrm{l}$ )

○- $154 \mathrm{mmol} / 1 \mathrm{NaCl}, 4 \mathrm{mmol} / 1 \mathrm{Tris} / \mathrm{HCl}$, and $30 \mathrm{mmol} / 1$ sucrose

- $154 \mathrm{mmol} / \mathrm{l} \mathrm{NaCl}, 4 \mathrm{mmol} / 1 \mathrm{Tris} / \mathrm{HCl}$, and $10 \mathrm{mmol} / \mathrm{l}$ inulin.

centration of bivalent anions or inulin in the suspension (fig. 1). When such "protective" substances are present in the external solution higher electric field strengths are then required to induce electrical haemolysis. The shift of haemolysis to higher electric field strengths observed for mouse red blood cells in the presence of these protective agents is similar to that previously reported for human red blood cells (13). The reader should consult this reference for the theoretical aspects of the experiments reported here. It should be pointed out that the effect of these protective substances on the haemolysis may result from a decrease in the kinetics of haemolysis. Some preliminary experiments support this point of view.

Since the electrically induced permeability change of the red blood cell membrane increases with increasing electric field strength, the "protective" influence of these substances can therefore be adequately used to adapt the loading process to the molecular weight of the drug or enzyme to be trapped inside the cells without actually requiring haemolysis.

The ghost cells lysed under the various conditions were resealed as outlined in the "Methods". In a set of preliminary experiments it was found that for directing methotrexate completely to the liver, application of a' field pulse of between $8 \mathrm{kV} / \mathrm{cm}$ to $12 \mathrm{kV} / \mathrm{cm}$ to mouse or human red blood cells suspended in solution II is optimal. Under these conditions complete haemolysis occurs for both human and mouse red blood cells (fig. 1) and ghost cells are obtained which are immediately capable of being degraded in the liver. This is also obvious from table 1 where the degradation of mouse ghost
Tab. 1. Distribution of $99 \mathrm{~m}$ Tc-labelled mouse red blood cell ghosts and intact red blood cells in different organs of mice. The values refer to the total amount of $T c$ injected and are average values from five and two measurements for the ghost and intact red blood cells, respectively.

\begin{tabular}{lllll}
\hline Organ & \multicolumn{2}{l}{$\begin{array}{l}\text { Red blood cell } \\
\text { ghosts }\end{array}$} & \multicolumn{2}{l}{$\begin{array}{l}\text { Intact red blood } \\
\text { cells }\end{array}$} \\
& \multicolumn{2}{l}{ Time (min) } & \multicolumn{2}{l}{ Time (min) } \\
& 10 & 30 & 10 & 30 \\
\hline Liver & 0.790 & 0.552 & 0.088 & 0.077 \\
Blood & 0.116 & 0.083 & 0.976 & 1.000 \\
Serum & 0.017 & 0.023 & 0.020 & 0.000 \\
Heart & 0.003 & 0.002 & 0.004 & 0.020 \\
Spleen & 0.033 & 0.045 & 0.011 & 0.010 \\
Kidney & 0.017 & 0.024 & 0.013 & 0.006 \\
Lung & 0.068 & 0.088 & 0.121 & 0.082 \\
Duodenum & 0.001 & 0.003 & 0.002 & 0.001 \\
\hline
\end{tabular}

cells prepared under these conditions was studied in vivo after labelling the membranes with ${ }^{99 m} \mathrm{Tc}$. It is evident that after $10 \mathrm{~min}$ about 0.80 of the injected ghost cell membranes accumulate in the liver, whereas the control experiments using labelled intact mouse red blood cells show no significant disappearance of radioactivity from the blood over a longer time interval. The latter experiment also allows the calculation of the blood volume of the mice, which was, on average, found to be $72.6 \mathrm{ml} / \mathrm{kg}$ body weight.

\section{Hom ogeneity of cells loaded with methotrexate} In order to achieve controlled drug release in time and space the cells of the ghost population loaded with the 
drug have to be homogeneous. The homogeneity of the ghost cell population was tested by measuring the size distribution as a function of increasing electric field strengths in the orifice of a hydrodynamic focusing Coulter Counter $(23,24,25)$. A typical size distribution of ghost cells from mice prepared electrically at $12 \mathrm{kV} /$ $\mathrm{cm}$ (see Methods) as a function of the electric field strength in the orifice is shown in figure 2. The size distributions are uniformly distributed over the whole range of the field strength. Dielectric breakdown of the cell membrane occurs beyond a critical field strength of $2.2 \mathrm{kV} / \mathrm{cm}$, indicated by the discontinuity in the straight line obtained when plotting the position of a given volume e. g. the channel number of the mean (modal) volume versus the electric field strength (fig. 2). The mean volume of the mouse ghost cell population, determined from the size distribution at low electric field strengths after calibration of the channels with Latex particles of known mean size, was $57 \mu \mathrm{m}^{3}$ using a shape factor of 1.1 for the deformed cells in the orifice (volume of intact mice red blood cell: 45 $\mu \mathrm{m}^{3}$ ). The shape factor was calculated from the ratio of the axis of intact red blood cells taken from photographs of the cells during their passage through a modified Coulter orifice (Pilwat \& Zimmermann, unpublished data). The shape factor is identical both for human and mouse red blood cells. Since the shape factor of the ghost cells cannot be determined by this equipment the value of the shape factor for the intact red blood cells was taken. The corresponding apparent breakdown voltage is about $1.4 \mathrm{~V}$, calculated on the basis of the integrated Laplace equation for elliptical cells (12). For human ghost cells the size distributions are also normally distributed over the whole electric field range. The mean volume in this case was $110 \mu \mathrm{m}^{3}$ and the apparent breakdown voltage about $1 \mathrm{~V}$. The mean volume of the ghost cells can be varied over a long range when performing the haemolysis in solutions, in which chloride was replaced by bivalent anions or by addition of sucrose and inulin (see above) or by transient osmotic shock (13). Loading of the ghost cells with drug under the experimental conditions delineated in the Methods Section, did not lead to any apparent alterations in the homogeneity of the ghost cell population (fig. 3). The size distributions of ghost cells of mice loaded with ca. $5 \mathrm{mmol} / 1$ methotrexate were uniformly distributed at low electric field strengths in the orifice of the Coulter Counter. There was also no significant skew in the size distributions in the presence of high electric field strengths (fig. 3). The mean volume of the loaded

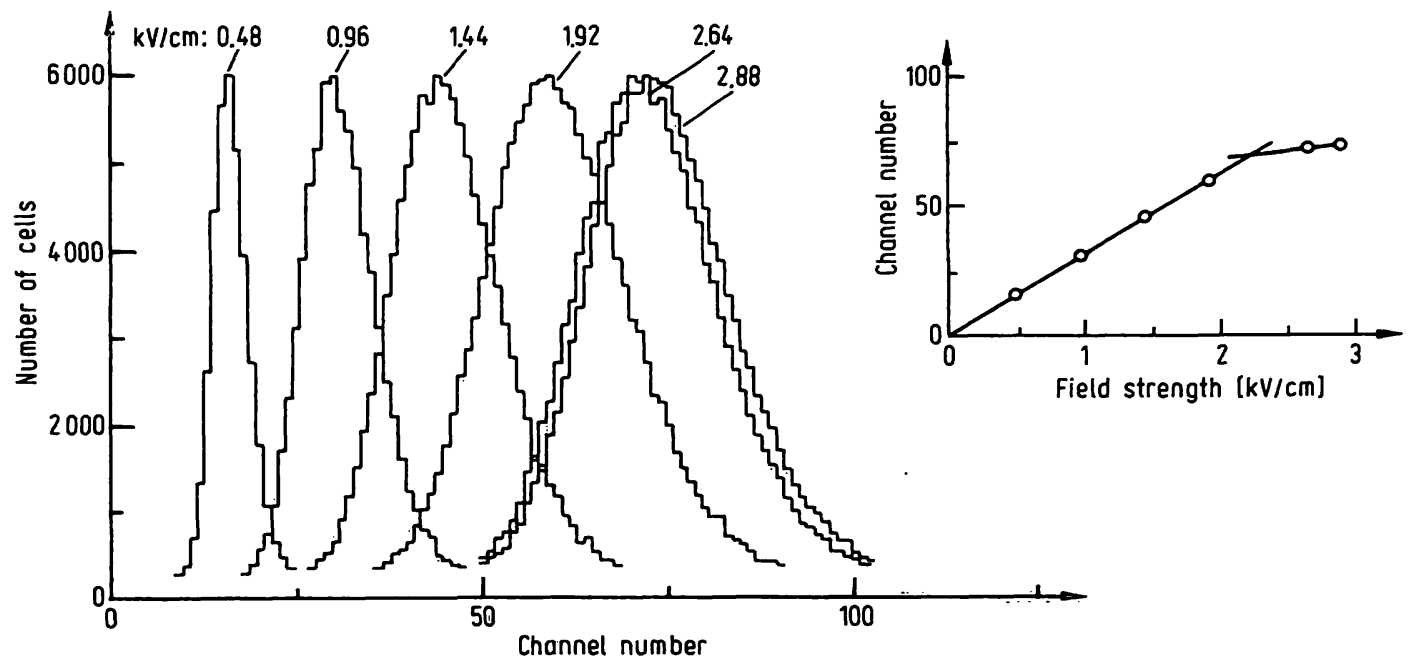

Fig. 2. Size distributions of mouse erythrocyte ghost cells measured as a function of increasing electric field strength in the orifice of a hydrodynamically focusing Coulter Counter (orifice dimensions: $60 \mu \mathrm{m}$ in length and diameter). The height of the voltage pulse generated by a cell during its passage through the orifice was electronically amplified and analyzed by a pulse height analyzier containing $16 \times 256$ channels $(25)$. The electronic amplification was kept constant over the whole field range. At low electric field strength, the pulse heights generated by the cells correspond to the size of the cells. The mean volume of the mouse ghost cells obtained after calibration of the channels with Latex particles (mean diameter $2.02 \mu \mathrm{m}$ ) was $57 \mu \mathrm{m}^{3}$. Above $2.2 \mathrm{kV} / \mathrm{cm}$ dielectric breakdown of the cell membrane occurs, indicated by an underestimation of the actual volume of the cells. This becomes evident when plotting the channel number of a given volume versus increasing field strength (see inset). A sharp discontinuity occurs at a givien field strength depending on the size (12). In this figure this effect is demonstrated for the mean volume $\left(57 \mu \mathrm{m}^{3}\right)$. The breakdown voltage of the cell membrane which is volume-independent $(24)$ is calculated from the apparent underestimation of the volume to be $1.4 \mathrm{~V}(12)$. Note that the size distributions are uniform over the whole field range. No skew is observed below or above the critical external field strength where breakdown occurs. Beyond the critical external field strength required for breakdown the size distributions become coincidental. This is to be expected as the conductivity of the ghost cell interior which is identical with that of the external solution determines the resistance for the whole cell for supercritical field strengths (25). As the current through the orifice is increased, the measured size distribution broadens owing to an increased sensitivity of the system, a result of the fixed resolution of the Analogue to Digital Converter combined with the increased amplifier output. The ghost cells were prepared electrically in isotonic and isoionic solutions by subjecting the cell suspension ( $1: 10$ packed cells to solution) to an electric field pulse of $12 \mathrm{kV} / \mathrm{cm}$ and $40 \mu \mathrm{s}$ duration. Haemolysis was conducted between $0-4^{\circ} \mathrm{C}$; the resealing process of the lysed cells was carried out for $10 \mathrm{~min}$ between $0-4^{\circ} \mathrm{C}$ and for a further $30 \mathrm{~min}$ at $37^{\circ} \mathrm{C}$. After several washing steps (see Methods) the resealed cells were transferred to solution $\mathrm{I}$ in which the size distributions of the ghost cell population were determined. 


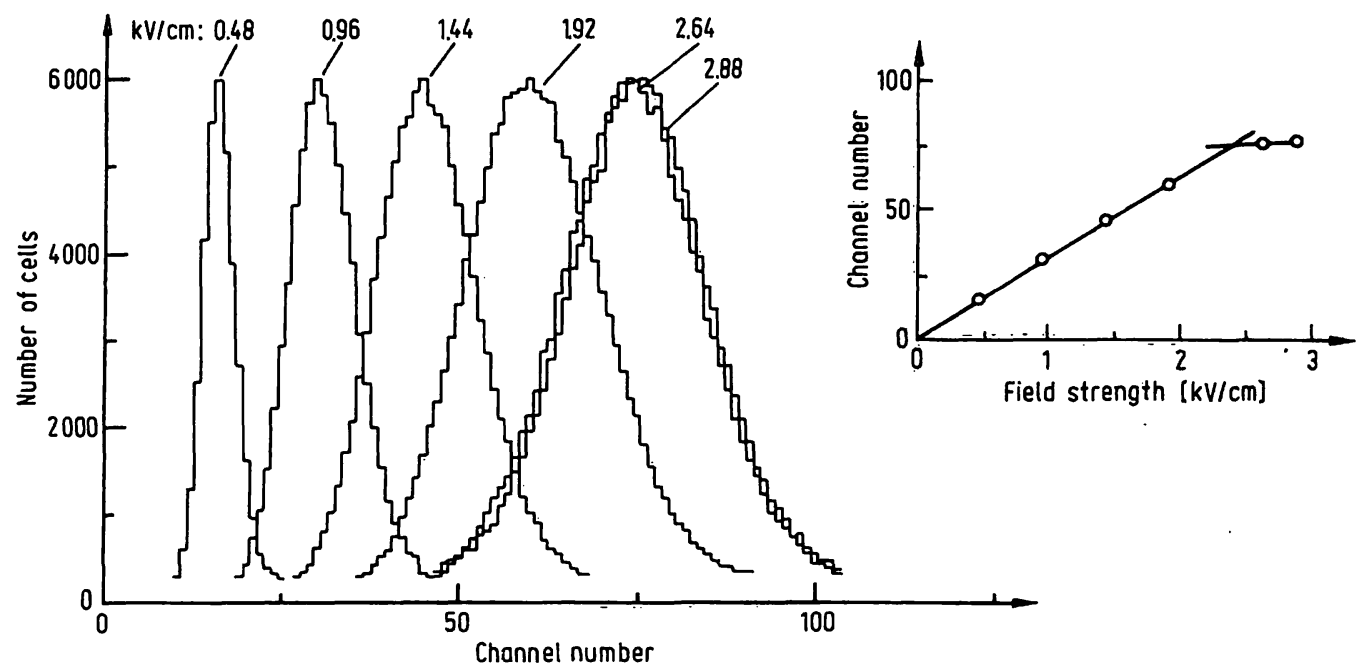

Fig. 3. Size distributions of mouse erythrocyte ghost cells containing $5 \mathrm{mmol} / \mathrm{l}$ entrapped methotrexate, measured as a function of increasing electric field strength. The experimental conditions are identical with those described in figure 2 with the exception that $5 \mathrm{mmol} / \mathrm{l}$ methotrexate were added to the isotonic solution before subjecting the cell suspension to the electric field pulse to cause haemolysis of the erythrocytes. Note that no significant skew occurs at higher electric field strengths in the orifice of the Coulter Counter, suggesting that the entrapment of methotrexate into the resealed ghost cells does not alter the electrical homogeneity of the ghost cell population.

mouse ghost cells is the same as that for the unloaded cells, namely $57 \mu \mathrm{m}^{3}$, but the breakdown voltage is slightly different $(1.5 \mathrm{~V})$. Similar results were obtained for loaded human red blood cell ghosts.

\section{Stability of the loaded ghost cells}

Figure 4 shows cumulative data from several measurements concerning the leakage rate of labelled methotrexate from mouse and human ghost cells at different temperatures in vitro. The ghost cells were incubated in solution I which is used for the injection. As indicated in figure 4, the loaded human ghost cells are stable over a period of $4 \mathrm{~h}$ without any significant leakage of methotrexate from the cells, independently of the temperature of the suspension. On the other hand, leakage of methotrexate from the mouse ghost cells does occur during this time interval. The leakage rate (about $0.07 / \mathrm{h}$ ) is identical both at low and room temperature over a four hour period. The leakage rate is also about 0.07 in the first hour at $37^{\circ} \mathrm{C}$, after which it increases. However, this finding is of no consequence for the loaded cells in the blood circulation, since the ghost cells are almost competely degraded in the liver after $10 \mathrm{~min}$ (see tab. 1). On the other hand, the loss of methotrexate from the cells observed at room or low temperature suggests that the data measured for the accumulation of methotrexate in the liver after $10 \mathrm{~min}$, when using. mouse ghost cells as the delivery system, will be underestimated by about 0.07 .

In order to demonstrate that storage of human ghost cells loaded with methotrexate is, in principle, possible over several days, we studied the stability of loaded human ghost cells suspended in aqueous citrate-glucose buffer stored at $4^{\circ} \mathrm{C}$ in the refrigerator. Aqueous citrate-

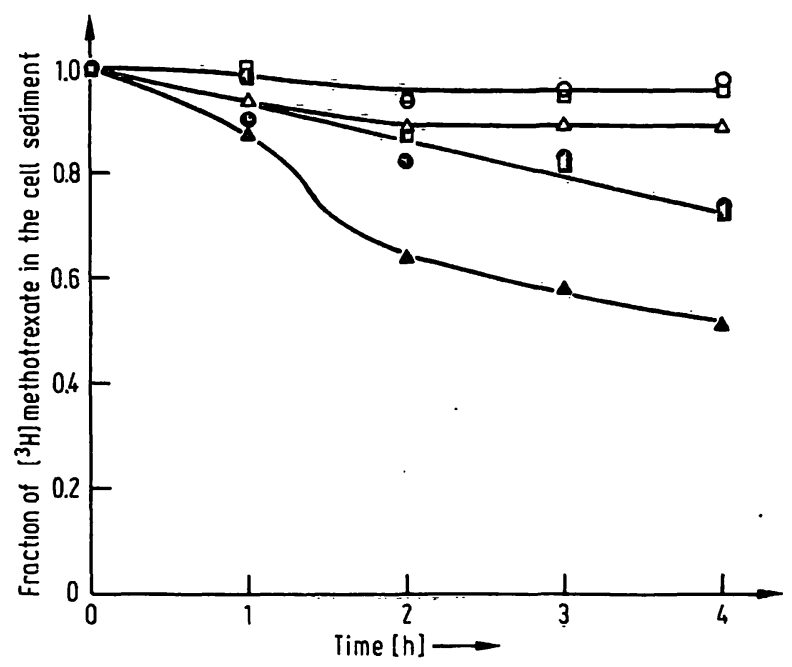

Fig. 4. Stability of mouse and human ghost cells loaded with methotrexate and suspended in solution I. The experiments were conducted at different temperatures $\left(\circ, \bullet 0^{\circ} \mathrm{C} ; \mathrm{\circ}, \| 20^{\circ} \mathrm{C}\right.$, and $\left.\Delta, \triangle 37^{\circ} \mathrm{C}\right)$. The loaded cells were prepared by electrical haemolysis, subjecting the cells suspended in solution II to a field pulse of $8 \mathrm{kV} / \mathrm{cm} ; 5 \mathrm{mmol} / 1$ methotrexate and $\left[{ }^{3} \mathrm{H}\right]$ methotrexate were added to the solution before field application. The resealed and loaded cells were incubated in solution I at a suspension density of 0.06 . Filled symbols refer to mouse ghost cells while the open symbols refer to human ghost cells. The radioactivity was determined in the ghost cell sediment of centrifuged aliquots taken from the suspension at different times. Average values of two different sets of experiments are presented.

glucose buffer was used successfully in storing intact red blood cells. From figure 5 it is obvious that a leakage of ca. 0.1 /day occurs. This seems to be relatively small, and we feel that the stability can be improved considerably, when we have more information concerning the conditions required to prolong the half-time of the loaded ghost cells. 


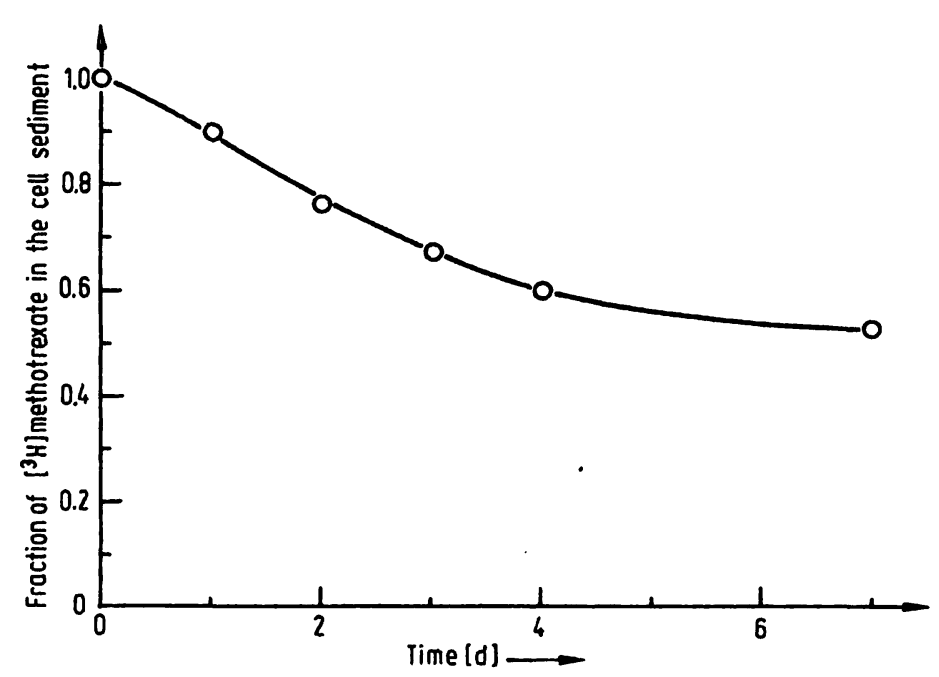

Fig. 5. Storage of methotrexate loaded human ghost cells in aqueous citrate-dextrose buffer at $4^{\circ} \mathrm{C}$. The loaded cells were prepared by electrical haemolysis $(8 \mathrm{kV} / \mathrm{cm}$ and 12 $\mathrm{kV} / \mathrm{cm}$ ) in solution II containing $5 \mathrm{mmol} / 1$ methotrexate and $1.9 \mathrm{GBq}{ }^{3} \mathrm{H}$ ]methotextrae. After resealing the cells were incubated in aqueous citrate-dextrose buffer at a suspension density of 0.10 (packed cells to solution). At different times, aliquots of the suspension were removed, centrifuged and the radioactivity determined both in the sediment $(0-0)$ and in the supernatant (not shown). The data points are average values of three different sets of experiments. The leakage of methotrexate from the ghost cells is independent of the field strength applied for electrical haemolysis.

\section{Distribution of methotrexate in the mouse}

Both human and mouse ghost cells were loaded with ca. $5 \mathrm{mmol} / 1$ methotrexate and $\left[3^{\prime}, 5^{\prime} 9(\mathrm{n}) \cdot{ }^{3} \mathrm{H}\right]$ methotrexate suspended in solution I. If not otherwise stated, the cell suspension density was $0.06 .200 \mu \mathrm{l}$ of this suspension was injected into the tail veins of the mice. Control experiments were conducted with the same amount of free methotrexate and $\left[{ }^{3} \mathrm{H}\right]$ methotrexate dissolved in the same amount of solution. The injection time was about $5 \mathrm{~s}$ and identical for both types of drug administration. The time course of $\left[{ }^{3} \mathrm{H}\right]$ methotrexate was then measured in the liver (fig. 6 and 7) over a $3 \mathrm{~h}$ span and in several organs, tissues and body fluids over a 1 h span (tab. 2) by killing several mice at given time intervals. As methotrexate is not metabolized in mice (31) it was considered to be valid to calculate the accumulated drug in specific organs and tissues from the drug count per organ (or per gram tissue and body fluid) in relation to the total amount of methotrexate and $\left[{ }^{3} \mathrm{H}\right]$ methotrexate injected into the vein. However, it should be noted that metabolism of methotrexate can occur in mice after $3 \mathrm{~h}$ due to intestinal bacteria (32).

The control experiments revealed that the drug applied in the normal administration form is eliminated almost completely by the intestine and kidney within the first two or three hours after injection. This is particularly obvious in those experiments (tab. 2) where the radioactivity pattern over the whole body of the mouse was investigated after 10, 30, and $60 \mathrm{~min}$. The drug con-

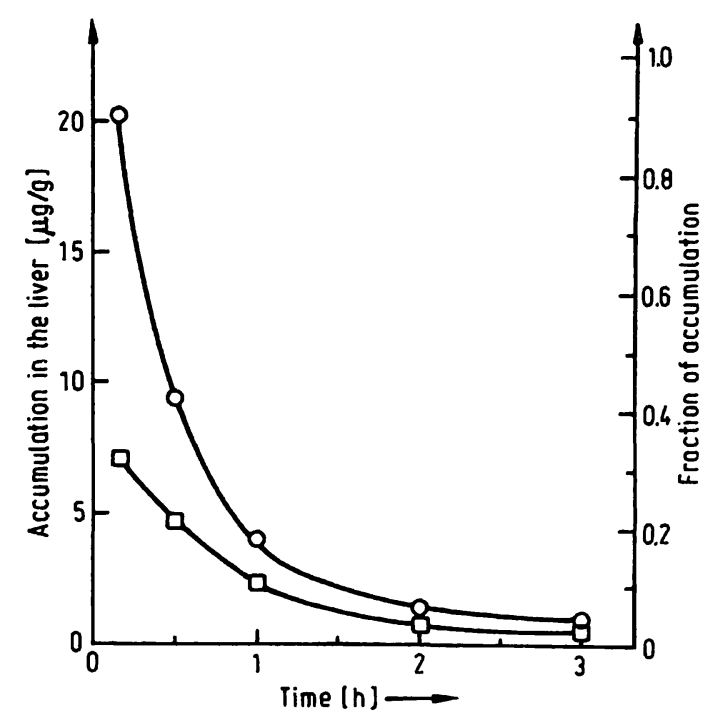

Fig. 6. Time course of $\left[{ }^{3} \mathrm{H}\right]$ methotrexate accumulation in the liver of mice after a single $i$. $v$. injection into the tail of the mice. Mouse red blood cells were loaded with methotrexate by electrical haemolysis in isotonic and isoionic solutions containing $5 \mathrm{mmol} / 1$ methotrexate and $\left[{ }^{3} \mathrm{H}\right]$ methotrexate (see Methods and Results, and fig. 3 ). For injection, the methotrexate loaded ghost cells were suspended in solution I at a suspension density of 0.05 and injected into the tail veins of mice (body weight $18-22 \mathrm{~g}$ ). This dose corresponds to $1.1 \mathrm{mg}$ methotrexate/kg body weight. The circles $(0-0)$ represent the accumulation of methotrexate in the liver over a $3 \mathrm{~h}$ period. On the lefthand scale accumulation is given in $\mu \mathrm{g} / \mathrm{g}$ liver weight, on the righthand scale as a fraction of the total amount of methotrexate injected. The values are an average of 6 measurements. In the control runs the same amount of methotrexate and $\left[{ }^{3} \mathrm{H}\right]$ methotrexate dissolved in the same amount of solution was injected into the tail veins and the time course of methotrexate in the liver over a $3 \mathrm{~h}$ period was determined $(0-0)$. Note the marked differences in the accumulation of methotrexate in the liver, depending on whether the drug is administered free or entrapped in ghost cells.

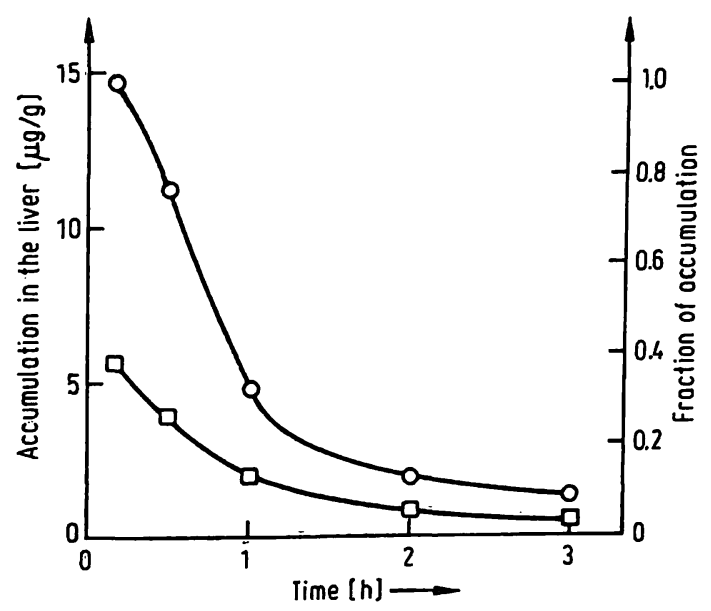

Fig. 7. Methotrexate was entrapped in human erythrocyte ghost cells by electrical haemolysis and injected into the tail veins of mice $(0-0)$. The time course of the accumulation of methotrexate was followed over a $3 \mathrm{~h}$ period. The experimental conditions were identical with those described in figure 6. Squares $(\square-0)$ correspond to the control runs, where free methotrexate and $\left[{ }^{3} \mathrm{H}\right]$ methotrexate was injected i.v. The values are an average of 6 measurements. 
Tab. 2. Distribution of $\left[3^{\prime}, 5^{\prime}, 9(n)-{ }^{3} \mathrm{H}\right]$ methotrexate in mice, 10,30 , and 60 min following i. v. administration of a suspen sion containing $50 \mathrm{~g} / 1$ methotrexate-loaded mouse ghost cells. The ghost cells were loaded with $5 \mathrm{mmol} / 1$ methotrexate by electrical haemolysis $(8$ to $12 \mathrm{kV} / \mathrm{cm})$. The average value of methotrexate entrapped in the cells was in the range of 0.80 , resulting in a dose of $1 \mathrm{mg}$ methotrexate per $\mathrm{kg}$ body weight. For the control, the same dose of free methotrexate was administered. The values in brackets refer to the number of experiments.

\begin{tabular}{lllllll}
\hline Organ & \multicolumn{2}{l}{$\begin{array}{l}\text { Methotrexate, encapsulated } \\
\text { Time (min) }\end{array}$} & & \multicolumn{2}{l}{ Methotrexate, free } \\
& 10 & 30 & 60 & 10 & 30 & 60 \\
\hline Liver & $0.790(15)$ & $0.394(15)$ & $0.222(15)$ & $0.300(9)$ & $0.210(9)$ & $0.085(9)$ \\
Blood & $0.078(13)$ & $0.070(13)$ & $0.053(11)$ & $0.048(8)$ & $0.030(7)$ & $0.022(5)$ \\
Serum & $0.033(11)$ & $0.022(11)$ & $0.044(11)$ & $0.023(8)$ & $0.016(8)$ & $0.011(6)$ \\
Heart & $0.004(11)$ & $0.007(11)$ & $0.013(11)$ & $0.002(5)$ & $0.006(4)$ & $0.006(4)$ \\
Spleen & $0.025(11)$ & $0.012(11)$ & $0.012(11)$ & $0.001(5)$ & $0.002(4)$ & $0.001(4)$ \\
Kidney & $0.024(11)$ & $0.020(10)$ & $0.021(11)$ & $0.017(5)$ & $0.012(4)$ & $0.005(4)$ \\
Lung & $0.010(11)$ & $0.014(11)$ & $0.009(10)$ & $0.004(5)$ & $0.002(4)$ & $0.001(4)$ \\
Duodenum & $0.033(11)$ & $0.049(11)$ & $0.042(11)$ & $0.050(3)$ & $0.047(3)$ & $0.010(2)$ \\
Intestine & $0.025(9)$ & $0.082(8)$ & $0.095(8)$ & $0.200(3)$ & $0.254(3)$ & $0.242(2)$ \\
Stomach & $0.012(10)$ & $0.011(8)$ & $0.006(5)$ & $0.004(2)$ & $0.007(2)$ & $0.002(1)$ \\
Bladder & $0.011(9)$ & $0.009(8)$ & $0.010(8)$ & $0.023(2)$ & $0.020(2)$ & $0.010(1)$ \\
Urine & $0.000(10)$ & $0.148(5)$ & $0.156(4)$ & $0.000(2)$ & $0.107 .(2)$ & $0.282(3)$ \\
Feces & $0.003(10)$ & $0.005(7)$ & $0.035(8)$ & $0.118(1)$ & $0.024(1)$ & $0.129(3)$ \\
\hline
\end{tabular}

centration in the liver measured 10 min after injection is ca. 0.30 and decays exponentially with a half time of ca. $30 \mathrm{~min}$. These results are in good agreement with those reported by Zaharko and colleagues $(20,33)$. The level of $\left[{ }^{3} \mathrm{H}\right]$ methotrexate in all other organs, tissues and fluids does not exceed 0.05 (with exception of the feces, intestine, and urine) of the injected dose.

The distribution pattern of $\left[{ }^{3} \mathrm{H}\right]$ methotrexate is, however, markedly different when methotrexate-loaded red blood cells are injected. 10 min after injection between 0.75 and 1.00 of the total dose is found in the liver. The level of $\left[{ }^{3} \mathrm{H}\right]$ methotrexate measured in the liver after $10 \mathrm{~min}$ following the single $i$. v. injection seems to be dependent upon the volume of the ghost cells which were used for the entrapment of the drug. When human red blood cell ghosts (fig. 7) were used, almost 0.90 to 1.00 of the injected dose was found in the liver $10 \mathrm{~min}$ after injection, whereas with mouse ghost cells only about 0.75 to 0.85 of the injected dose was measured in the liver at this time. This lower accumulation found for mouse ghost cells may also be partially explained by the small leakage rate of methotrexate from mouse ghost cells during the time interval between preparation and injection as mentioned above. Another reason may be variations in the time interval after injection at which the peak value of accumulation in the liver occurs. This was indicated in experiments where samples were taken between 5 and 10 min showing that the peak values lie within this time interval. The level of methotrexate in the liver decreased exponentially, showing the same time constant as observed when free methotrexate is injected; the control values were reached after 2 to $3 \mathrm{~h}$. Increasing the cell suspension density up to 0.5 does not significantly change the distribution of methotrexate.

It is well known that part of the methotrexate is bound to serum proteins (31). For this reason, it can be argued that the differences in the radioactivity pattern result from binding of the drug to the ghost cell membrane proteins. This conclusion seems to be supported by the finding that ca. 0.80 of the ${ }^{99 \mathrm{~m}}$ Tc-labelled mouse ghost membranes were detected in the liver after $10 \mathrm{~min}$ (tab. 1). However, in vitro experiments show that methotrexate trapped inside ghost cells is unbound and can be almost completely released from the cells when subjected to hypotonic stress. Under these conditions, more than ca. 0.90 to 0.95 of the trapped methotrexate was measured in the supernatant; that means that only ca. 0.05 of the trapped drug is adsorbed on the membrane surfaces.

\section{Discussion}

The results reported here demonstrate the effectiveness of drug administration by using red blood cells as drug delivery systems. Up to 1.0 of the injected dose could be directed to the liver. This result can be considered to be a considerable progress in the treatment of liver tumours especially when comparing it with the value of 0.5 recently published by Zimmermann \& Pilwat (3) using the red blood cell carrier system. While this paper was in preparation, Tyrell \& Ryman (34) described some preliminary experiments in which they studied the entrapment of methotrexate in ghost cells prepared by osmotic haemolysis. The concentration of methotrexate in the external solution in which osmotic haemolysis was conducted was only about $50 \mathrm{mg} / 1(0.1 \mathrm{mmol} / \mathrm{l}) .0 .035$ of methotrexate was trapped inside the resealed ghost cells, i. e. a considerably smaller amount than that trapped by the electrical haemolysis. On the basis of the adsorption experiments described here we feel strongly that the values reported by Tyrell \& $R$ yman reflect more adsorption on the membrane surface than real 
entrapment of the drug inside the cells. Unfortunately, the authors present no control experiments in which the amount of drug adsorbed on the membrane surface was determined. The homogeneity of the methotrexateloaded ghost population was also not investigated by these authors. We consider it important to prepare homogeneous ghost preparation in order to achieve a controlled drug release in time and space. The electrical haemolysis method, based on the dielectric breakdown of the cell membrane in response to an external electric field pulse, offers the possibility both of trapping large quantities of drugs inside the ghost cells under isotonic conditions and of detecting any inhomogeneities in the ghost cell preparation by use of dielectric breakdown measurements on the resealed ghost cells in the modified Coulter Counter.

A further decisive advantage of the electrical method over the osmotic one is that the permeability changes induced in the membrane can be adequately matched to the molecular weight of the drug or enzyme to be entrapped without actually requiring haemolysis. This has already been shown recently by trapping urease in human red blood cells (10).

It is obvious, however, that a broader use of cells as delivery systems for drugs and enzymes will demand targeting of these carriers to other selected sites of tissues and organs. Targeting of drugs to other sites than the liver can probably achieved by using lymphocytes or other living cells for drug entrapment. Since dielectric breakdown is a general phenomenon occurring in membranes of all living cells $(35,36)$ including lymphocytes (unpublished data) it would appear that the electric field pulse method presented here is the method of choice to trap drugs in cellular envelopes.

A more promising way as we feel to direct carrier systems to other target specificity is to use "modified" red blood cells. A priori the target specificity of red blood cells seems to be restricted to the spleen and liver. The electrical haemolysis method allows in principle the preparation of red blood cells loaded with drug which have still haemoglobin and identical properties compared with those of the intact cells in respect to size, surface charge, and deformability (see above). The life-span of such cells may be much greater than that of those ghost cells used for directing the drug to the liver. The maximum life-span cannot, however, exceed the life-span of the intact red blood cells in any way. Thus, these cells will also be degraded in the liver if they are not captured during circulation in the blood at another selected site of the body. The difficulty in providing the cells with intrinsic specificity for other sites can be overcome by simultaneous entrapment of para-, ferro-, or ferrimagnetic particles, together with the drug, in the red blood cells. Provided that such loaded cells have a life-span of at least $30 \mathrm{~min}$, an accumulation of the cells loaded with magnetic fine particles at any selected site of the body can be achieved by external application of magnetic fields. External magnetic devices capable of providing magnetic field gradients large enough to guide magnetic catheters have been developed in the last 15 years $(37,38)$. The magnetic fields generated by these devices are also strong enough to direct red blood cells containing magnetic particles to the desired location in the body. Magnetic particles of sizes of the order of 4-20 nm are available (39) and in vivo experiments with these fine particles by Nakamura et al. (40) have shown that they can be easily removed from the blood either by chemical agents or by extracorporal bypass circulation systems where the magnetic fine particles are collected with magnetic fields. Thus, severe complications should not occur in the body when the particles are released. The temporal release of the drug and, in turn, of the magnetic particles at selected sites of the body can be achieved either by adjusting the stability of the cell membrane via the field application by entrapping small amounts of enzymes which degrade the membrane (41), or by dielectric breakdown of the cells in vivo. Such multicomponent systems were recently shown, in a preliminary experiment, to be operational in vitro.

Thus the red blood cell system undoubtedly represents a significant step forward in the development of a new drug delivery system, when electrical methods are used for the entrapment. It must be stated, however, that much effort is needed to improve the carrier system.

Finally, it should be pointed out that several authors have suggested an alternative carrier system for drugs, that is the use of liposomes (42). Recently, Kimelberg et al. (43) suggested the entrapping of methotrexate in positively charged liposomes. These authors demonstrated in very elegant experiments, that the distribution pattern of methotrexate in a cynologous monkey (Macaca irus) changes markedly when methotrexateloaded liposomes are injected, in comparison with the controls. At the present experimental stage it is not possible to decide which carrier system may be more successful, particularly for targeting drugs to any selected site of the body.

The studies of these and other authors show that the liposomes are tolerated after in vivo administration and that drugs and pharmacologically active materials can be injected into cells in both in vitro and in vivo situations. Kimelberg et al. also showed that the liposomes are stable for $4 \mathrm{~h}$ in the blood circulation. On the other hand the preparation of methotrexate entrapped liposomes comprises numerous steps in order to obtain homogeneous preparations, whereas the electrically loading process of the red blood cells with drugs is a single step preparation. More importantly the amount of methotrexate trapped inside the ghost cells is much 
higher than the percentage of entrapment reported by Kimelberg et al. (42) for liposomes. It should also be pointed out that it was not possible to direct the methotrexate loaded liposomes completely to the liver or spleen. Difficulties in using liposomes may also arise in the trapping of small magnetic particles which we believe might hold considerable promise as a potential tool for target specific drug delivery. However, a combined system made of liposomes and cells may be the most effective therapeutic system in the future (41).

\section{Acknowledgement}

The authors are indebted to H.J. Buers and Miss $K$. Bock for their very expert technical assistance.

This work was supported by grant No. BCT 112 from the BMFT, Bonn.

\section{References}

1. Michaels, A. S., Mader, W. J. \& Manning, C. R. (1975), Proceedings of the 35th Inter national Congress of Pharmaceutical Sciences, Dublin, Ireland, September 1-5, in press.

2. Zaborsky, O. (1972), In Immobilized Enzymes (Weast, R. C., ed.), Chapter 7, pp. 93-100, CRC Press, Cleveland, Ohio.

3. Zimmermann, U. \& Pilwat, G. (1976), Z. Naturforsch. C31, $732-736$.

4. Zimmermann, U., Pilwat, G., Buers, H. J. \& Bock, K. (1976), Dtsch. Bundes-Patentanmeldung P 2655801.0 vom 9. 12. 1976.

5. Zimmermann, U., Pilwat, G., Buers, H. J. \& Bock, K. (1976), Dtsch. Bundes-Patentanmeldung P 2656746.4 vom 15. 12. 1976.

6. Zimmermann, U., Pilwat, G. \& Riemann, F. (1976), Dtsch. Bundes-Patent P 2405119 vom 2. 2. 1974.

7. Zimmermann, U. (1973), Dtsch. Bundes-Patentanmeldung P 2326161 vom 23. 5. 1973. Schweizer Patent 582530.

8. Zimmermann, U. (1973), Jahresbericht der Kernforschungsanlage Jülich $\mathrm{GmbH}, \mathrm{pp} .55-58$.

9. Zimmermann, U. (1975), Chem. Eng. News, Febr. 24, p. 21.

10. Zimmermann, U., Riemann, F. \& Pilwat, G. (1976), Biochim. Biophys. Acta 436, 460-474.

11. Ihler, G. M., Glew, R. H. \& Schnure, F. W. (1973), Proc. Nat. Acad. Sci. USA 70, 2663-2666.

12. Zimmermann, U., Pilwat, G., Beckers, F. \& Riemann, F. (1976), Bioelectrochem. Bioenerg. 3, 58-83.

13. Zimmermann, U., Pilwat, G., Holzapfel, Chr. \& Rosenheck, K. (1976), J. Membrane Biol. 30, 135-152.

14. Anderson, L. L., Collins, G. J., Ojima, X. \& Sullivan, R. D. (1970), Cancer Res. 30, 1344-1348.

15. Condit, P. T. (1971), Ann. N. Y. Acad. Sci., 186, 475-485.

16. Freeman-Narrod, M. (1962), In Methotrexate in the Treatment of Cancer (Porter, R. \& Wiltshaw, E., eds.), pp. 17-22, J. Wright and Sons, Bristol.

17. Wilmanns, W. (1971), Internist 12, 127-135.

18. Wilmanns, W. \& Maring, H. (1968), Klin. Wochenschr. 46, $281-296$.

19. Bertino, J. R. (1975), In Handbook of Experimental Pharmacology (Sartorelli, A. C. \& Johns, D. G., eds.), Chapter 52, pp. 468-483, Springer-Verlag, Berlin-Heidelberg-New York.

20. Zaharko, D. S., Dedrick, R. L., Bischoff, K. B., Longstreth, J. A. \& Oliverio, V. T. (1971), J. Nat. Cancer Inst. 46, 775-784.

21. Creaven, P. J., Hansen, H. H., Alford, D. A. \& Allen, L. M. (1973), Brit. J. Cancer 28, 589-591.

22. Riemann, F., Zimmermann, U. \& Pilwat, G. (1975), Biochim. Biophys. Acta 394, 449-462.
23. Zimmermann, U., Pilwat, G. \& Riemann, F. (1974), Biophys. J. 14, 881-899.

24. Zimmermann, U., Pilwat, G. \& Riemann, F. (1974), In Membrane Transport in Plants (Zimmermann, U. \& Dainty, J., eds.), pp. 146-153, Springer-Verlag, Berlin-HeidelbergNew York.

25. Zimmermann, U., Schulz, J. \& Pilwat, G. (1973), Biophys. J. 13, 1005-1013.

26. Hedge, U. M., Williams, E. D., Lewis, S. M., Szur, L., Glass, H. I. \& Pettit, J. E. (1973), J. Nucl. Med. 14, 769-771.

27. Updike, S. J., Wakamiya, R. T. \& Lightfoot, Jr., E. N. (1976), Science 193, 681-683.

28. Adriaenssens, K., Karcher, D., Lowenthal, A. \& Terheggen, H. (1976), Clin. Chem. 22, 323-326.

29. Marchesi, S. L., Steers, E., Marchesi, V. T. \& Tillack, T. W. (1970), Biochemistry 9, 50-57.

30. Mitchell, C. D. \& Hanahan, D. J. (1966), Biochemistry 5, 51-57.

31. Henderson, E. S., Adamson, R. H., Denham, C. \& Oliverio, V. T. (1965), Cancer Res. 25, 1008-1017.

32. Oliverio, V. T. \& Zaharko, D. S. (1971), Ann. N. Y. Acad. Sci. USA 186, 387-399.

33. Bischoff, K. B., Dedrick, R. L., Zaharko, D. S. \& Longstreth, J. A. (1971), J. Pharm. Sci. 60, 1128-1133.

34. Tyrell, D. A. \& Ryman, B. E. (1976), Biochem. Soc. Trans. 4, 677-680.

35. Coster, H. G. L. \& Zimmermann, U. (1975), J. Membrane Biol. 22, 73-90.

36. Zimmermann, U. (1977), In Integration of Activity in the Higher Plant, Proceedings of 31th Symposium of the Society of Experimental Biology (Jennings, D. ed.), Cambridge Publisher, in press.

37. Frei, E. H. (1970), C. R. C. Critical Review in Solid State Sciences, 381-407.

38. Yodh, S. B., Pierce, N. T., Weggel, J. \& Montgomery, D: B. (1968). Med. Biol. Engng. 6, 143-147.

39. Granquist, C. G. \& Buhrmann, R. A. (1976), J. Appl. Phys 47, 2200-2219.

40. Nakamura, T., Konno, K., Moroné, T., Tsuỳa, N. \& Hatano, M. (1971), J. Appl Phys. 42, 1320-1324.

41. Zimmermann, U. \& Pilwat, .G. (1976), Dtsch. Bundespatentanmeldung P 2656317 vom 3. 12. 1976.

42. Papahadjopoulos, D., Poste, G., Vail, W. J. \& Biedler, J. L. (1976), Cancer Res. 36, 2988-2994.

43. Kimelberg, H. K., Fracy, Jr., T. F., Biddlecome, S. M. \& Bourke, S. B. (1976), Cancer Res. 36, 2949-2957.

Prof. Dr. U. Zimmermann

Institut für Biophysikalische Chemie / ICH 2

Kernforschungsanlage Jülich $\mathrm{GmbH}$

Postfach 1913

D-5170 Jülich 